\title{
Jan Zabłocki
}

\section{Si mulier vinum bibit condemnatur}

Prawo Kanoniczne : kwartalnik prawno-historyczny 32/1-2, 223-232

1989

Artykuł został zdigitalizowany i opracowany do udostępnienia w internecie przez Muzeum Historii Polski w ramach prac podejmowanych na rzecz zapewnienia otwartego, powszechnego i trwałego dostępu do polskiego dorobku naukowego i kulturalnego. Artykuł jest umieszczony w kolekcji cyfrowej bazhum.muzhp.pl, gromadzącej zawartość polskich czasopism humanistycznych i społecznych.

Tekst jest udostępniony do wykorzystania w ramach dozwolonego użytku. 


\section{JAN Z,ABEOCKI}

\section{SI MULIER VINUM BIBIT CONDEMNATUR}

$\mathrm{Na}$ czele rodziny rzymskiej stał niezależny od nikogo naczelnik domu - pater familias, którego wkadzy podlegała cała familia. Wyrażenie pater familias składa się ze zbitki słów, z kiórych każde ma wielorakie znaczenie. Termin pater 1 oznacza rodzica, chociaż jest używany także $w$ odniesieniu do glowy rodu (pater gentis). Również czlonkowie senatu nazywani są patres. Tytuł pater odnosi się ponadto do bóstw np. pater Nepiunus, czy mitycznych przodków jak np. pater Aeneas 2. Także termin familia jest wieloznaczny ${ }^{3}$. $Z$ punktu widzenia prawnego oznaciza on calość zlożoną $z$ osób i rzeczy 4 . W węższym znaczeniu obejmowano tą mazwą albo wolne osoby powiązane ze sobą węzłami prawnymi, albo przynależny do tych osób majątek wraz $z$ niewolnikami. W najwęższym znaczeniu pod tą nazwą rozumiano niewolników (famuli) 5 .

Pojęcie pater familias oznarza zarówno właściciela majątłu jak i zwierzchnika osób będących pod jego wladzą ${ }^{6}$, który jest glową domu i symbolem trwania rodziny; pośrednikiem między duchami przaodków i żyjącymi 7 .

Pater familias będąc pośrednikiem między przodkami i resztą

$1 \mathrm{Na}$ temat etymюlogii showa pater por. A. W a 1 de - J. B. Hoff $\mathrm{m}$ a in $\mathrm{n}$, Lateinisches etymologisches Wörterbuch ${ }^{3}$, II, Heidelberg 1954, s.v. Pater, s. 262 i n.

$2 \mathrm{Na}$ temat różnorakiego znaczenia terminu pater w źródlanh por. Ae. Forcellini, Lexicon Totius Latinitatis, III, Patavii 1940, s.v. Pater, s. 592 i n. Por. też C. L o ng o, Corso di diritto romano, Diritto di famiglia, Milano 1946 , s. 6 i in.

3 Na temat etymologil słowa familia por. A. Waide - J. B. Hoff $\mathrm{m}$ a n, dz. cyt., I, Heidelberg 1938, s.v. Famulus, Familia, s. 452.

${ }_{4}$ Por. M. Kaser, Das römische Privatrecht', I, München 1971, s. 50 .

5 Punktem wyjścia na o:znaczenie poszczególnych kręgów rodziny jest komentarz Ulpiana do edyktu (D. 50.16.195.1-5). Por. też M. W yszyński, Prawo rzymskie, II, Prawo familijne, Warszawa 1953, s. 23; M. K a s e r, $R P R^{2}$, I, s. 50 i n. z cytowaną tam literaturą.

6 Por. M. Kas er, Der Inhalt der patria potestas, ZSS Rom. Abt. 58 (1938) S. 62 i n.

7 Por. C. W. Westrup, Introduction to Early Roman Law, I, Copenhagen-London 1914, s. 45 i n.; P. De Framcis ci, Primordia civitatis, Romae 1959, s. 151 i n. 
rodziny jest dla rodziny postacią centralną, której podporządkowani są wszyscy jej członkowie. Jednocześnie osoby podległe władzy patris familia, wchodzace $w$ skład rodziny, dzieliły $z$ nim stanowisko społeczne, polityczme, korzystały z jego opieki, a po jego śmierci $z$ reguly dziedziczyły jego mająteik $i$ kult 8 . Naczelnikiem rodziny mającym władzę nad podległymi osobami, jak wskazuje sama nazwa - pater familias, mógł być tylko mężczyzna, obywatel rzymski. Zaznaczyć jednak należy, iż pater familias oznacza stanowisko prawne w rodzinie. Może zajmować je nawet niedojrzaly - impuber, jeszcze niezdollny do rodzenia dzieci, czy dorosły pozbawiony już zstępnych, a także syn emancypowany, który posiada żyjącego ojca ${ }^{9}$.

Władza patris familias, pierwotnie jednolita w stosumku do wszystkich osób, była jeszcze w okresie Ustawy XII Tablic mało zróżnicowana i nazywała się manus. Pojęcie to oznaczało rękę - rękę karzącą, strzegącą, wspomagającą. Ale juz w tym okresie można zauważyć pewne zróżnicowanie władzy patris familias w stosunku do poszczególnych członków rodziny. Nad dziećmi mial on władzę zwaną patria potestas. Dla określenia jego uprawnień $\mathrm{w}$ stosilnku do zony (a w tym okresie żony $w$ zasadzie podlegały władzy swych męźów) zachowano dawną nazwę - manus, wreszcie władza nad niewolnikami, zwłaszcza w późniejsizym okresie, zwana była dominica potestas 10 .

Źródla dotyczace pierwotnych reguł kierujących życiem rodzinnym są nieliczne. Wśród nich na szczególną uwagę zasługują Noctes Atticae Aulusa Gelliusa, w których antykwarysta przytacza liczne przekazy sitarrożytnych autorów o życiu codziennym Rzymian wskazujące na władzę karania żony przez męża; $m$. in. podaje informacje o zakazie picia wina przez kobiety $i$ skutkach jakie pociagalo za sobą przekroczenie tego zakazu 11.

Gell. 10.23.1-2:

Qui de victu atque cultu populi Romani scripserunt mulieres Romae atque in Latio ,aetatem abstemias egisse", hoc est vino semper, quod "temetum" prisca lingua appellabatur, abstinuisse dicunt, institutumque ut cognatis osculum ferrent deprehendendi causa, ut odor indicium faceret, si bibissent. Bibere autem solitas ferunt loream, passum, murrinam et quae id genus sapiant potu dulcia.

\footnotetext{
${ }^{8}$ Por. C. W. W estrup, dz. cyt., I, s. 19; M. Ka ser, $R P R^{2}$, I, s. 51 .

9 Por. C. Longo, Diritto di famiglia, s. 7.

${ }_{10}$ Por, M. K a sier, $R P R^{2}, 1$, s. 56 i n. $z$ cytowana literaturą.

$11 \mathrm{Na}$ temat różnych teorii wyjaśniających powstanie zakazu pioia wina przez kobiety por. ostatnio L. IM in i eri, ,Vini usus feminis ignotus", LABEO 28 (1982) s. 150 i $n$.
} 
Jak podaje Gellius, autorzy piszący de victu et cultu narodu rzymskiego przekazali, że zarówno w Rzymie jak i w Lacjum kobiety prowadziły wstrzemięźliwy żywot, czyli, że zawsze powstrzymywały się od picia wina, nazywanego $w$ pierwotnym języku temetum. Picie takiego wina - temetum było kobietom zakazane; mogły pić jedynie niesfermentowany sok winogron (lorea), napój z jagód suszonych (passum), napój przyprawriony wonnością mirry (murrina) i inne lagodne napoje 12.

W celu skutecznej kontroli trybu życia kobiet wymyślono szczególny sposób postępowania. Mianowicie kobiety miały całować krewnych w usta, aby ci mogli po zapachu rozpoznać czy piły one wino ${ }^{13}$.

Stwierdzenie, że kobieta piła wino pociągało za sobą poważne konsekwencje.

Dion. 2.25.6 = Leges regiae, Romulus 7 (FIRA I, 7):

De his cognoscebant cognati cum marito: de adulteriis et si qua vinum bibisse argueretur; hoc utrumque enim morte punire Romulus concessit.

Dionysios mówi o przestępstwie kobiety, które polegało zarówno na cudzołóstwie jak i na piciu wina. Kobieta pijąca wino winna być ukarna $z$ taką samą surowością jak niewierna. W roli sędziego występował mąż i syngeneis. To ostatnie słowo greckie w thumaczeniu na język laciński brzmi - cognati 14. Wydaje się więc, iż upoważniony do karania kobiet - może w ramach tzw. iudicium domesticum 15 - był ten sam krąg osób, który wg Gelliusa zobowiązane były one całować.

\footnotetext{
12 Por. C. W. Westrup, dz. cyt., I, s. 201 i n.; L. Minieri, dz. cyt., s. 157 i $n$.

13 Por. Plin. Nat. Hist. 14.90: Cato ideo propinquos feminis osculum dare, ut scirent an temetum olerent. hoc tum nomen vino erat, unde et temulentia appellata. Geneza tego zwyczaju jest w źródłach różnie wy jaśniana. Por. K. S chneider, RE X, Stuttgart 1919, s.v. Ius osculi, szp. 1284; C. W. We strup, dz. cyt., I, s. 200 uw. 1; P. Noailles, Le tabous du mariage dans le droit primitif des Romains. Fas et Jus. Etudes de droit romain, Pamis 1948, s. 16 i n.; L. M in i e ri, dz. cyt., s. 156 .

14 Por. Festus, De verborum significatu, s.v. Osculana pugna, L. $216, \ldots$ quod inter cognatos, propinquosque institutum ab antiquis est, maximeque feminas ..., mówi nie tylko o krewnych, lecz if bliskich. Por. też W. K unkel, Das Konsilium im Hausgericht, ZSS Rom. Abt. 83 (1966) s. 236, który pod pojęciem syngeneis rozumie nie tylko krewnych męża, lecz przede wszystkim krewnyich żony.

15 Istnienie iudicium domesticum jako instytucji prawnej kwestionują Th. Mommsen, Römisches Strafrecht, Leipzig 1899 (Nachdruck, Graz 1955), s. 17 uw. 1; E. Volterra, Il preteso tribunale domestico in diritto romano, RISG 2 (1948) s. $108 \mathrm{i} \mathrm{m}$.; M. $\mathrm{K}$ a s e $\mathrm{r}$, Der Inhalt der patria potestas, s. 68 i n. Natomiast za iudicium domesticum jako instytucja prawną opowiada się R. D üll, Iudicium domesticum abdicatio und apoceryxis, ZSS Rom. Abt. 53 (1943) s. 59 oraz W. K u n-
} 15 - Prawo Kanoniczne 
Wiadomości o innych przestępstwach kobiet, traktowanych równie surowo przez ustawodawstwo Romulusa, podaje także Plutarch.

Plutarchus, Romulus 22 = Leges regiae, Romulus 9 (FIRA I, 8): Constitut quoque leges quasdam, inter quas illa dura est, quae uxori non pemittit divertere a marito, at marito permittit uxorem repudiare propter veneficium circa prolem vel subiectionem clavium vel adulterium commissum;...

Wedkug Plutarcha Romulus uznaje jako sluszny powód do rozwoáu oprócz cudzolóstwa (moicheutheisan) i veneficium circa prolem ${ }^{16}$ (farmakeia teknon) równiez popełnienie kleidon hypobole 17. Znaczenie tego zwrotu jest wątpliwe. Na język laciński zwrot kleidon hypobole jest thumaczony jako subiectionem clavium czyli zabranie kluczy ${ }^{18}$. Nie oznacza to zabrania kluczy od domu, bowiem żona wchodząc pod władzę męża otrzymywala klucze jako symbol istnienia małżenstwa cum manu, a które odbierano jej po rozwodzie na znak utraty nad nia władzy męża ${ }^{10}$. Mogły to być klucze do piwnic $z$ winem na co zdaje się wskazywać Pliniusaz.

Plin. Nat. Hist. 14.89:

... Fabius Pictor in annalibus suis scripsit matronam, quod loculos in quibus erant claves cellae vinariae resignavisset, a suis inedia mori coactam,...

Historyk podaje za Annales Fabiusa Pictora, że matrona rzymska została skazana na śmierć głodową za odpuieczętowanie szkatułki, w której trzymano claves cellae vinariae 20 . W tym przy-

kel, dz. cyt., s. 249 uw. 66. E. Pólay, Das, ,regimen morum" des Zensors und sogenannte Hausgerichtsbarkeit, Studi Volterra, III, MIilano 1971, s. 317 dowodzi, iz iudicium domesticum stoi na pograniczu instytucji prawnej i pozaprawnej.

${ }_{10}$ P. F. Girard, Textes de Droit Romain 5 , Paris 1923, s. 6 uw. 2 ma: propter veneficium vel suppositionem partus on w literaiturze jesit tłumaczone jako trucie dzieci, czy abortus procuratio. Por. C. W. W estrup, dz. cyt., I, s. 78; P. Noailles, dz. cyt., s. 2 i n.; A . SölIner, $Z u$ Vorgeschichte und Funktion der actio rei uxoricie, Köln-Wien 1969, ss. 75; M. Ka ser, RPR ${ }^{2}$ I, s. 61.

17 Odmienna lekcje tekstu greckiego proponuje E. A. Skassis, Diorthotika eis Ploutarchon, Tessarakontaetenis Theofililou Borea, 105108. Athen 1939 (cyt. za H. Krelle r, ZSS Rom. Abt. 60 (1940) s. 320), który w miejsce kleidon hypobole wstawia kai paidon hypobole.

13 P. F. Girard, Textes, s. 6 uw. 2 tłumaczy zwrot kleidon hypobole na falsationem clavium. Sens tego zwrotu $w$ języku polsksim najlepiej oddają słowa podroibienie, fałszowanie kluczy.

19 Wedlug Cic. Phil, 2.28.69 zgodnie z Ustawą XII Tablic (FIRA I, 36 - tab. 4.3) rozwiedzionej małżonce odbierano klucze symbolizujące wladze pani domu. Por. P. Bonfante, Corso di diritto romano, I, Diritto di famiglia ${ }^{2}$, Milano 1963, s. 335.

20 Por. Tert. Apol. 6.29: Cirea feminas quidem etiam illa maiorum 
padku, podobnie jak w przypadku przytoczonym przez Gelliusa (Gell. 10.23.1), do kontroli, a zdaniem Dionysiosa (Dion. 2.25.6) równocześnie do karania, uprawnieni byli krewini żony.

Gellius, w dalszym ciagu cytowanej relacji, przeciwstawia pierwotną formę kontroli i karania za picie wina innym konsekwencjom istniejacym juz w czasach Kabona.

Gell. 10.23.3:

Atque haec quidem in his quibus dixi libris pervulgata sunt, sed Marcus Cato non solum existimatas, set et multatas quoque a iudice mulieres, refert, nom minus si vinum in se, quam si probrum et adulterium admisissent.

Antykwarysta w słowie wprowadzającym do mowy Katona De dote, którą przytacza w dosłownym brzmieniu w dalszej części swojego wywodu, mówi, że wg Katona za picie wina kobiety nie tylko mogły być existimatas, lecz talkże multatas z taką samą surowością jak za probrum czy adulterium 21.

Nie ulega wątpliwości, że oudzołożnica złapana na gorącym uczynku mogła być bezkarnie przez męża zabita.

Gell. 10.23.5:

De iure autem occidendi ita scriptum: „In adulterio uxorem tuam si prehendisses, sine iudicio inpune necares; illa te, si adulterares sive tu adulterarere, digito non auderet contingere, neque ius est."

W swojej mowie De dote Kato uznał 22, iż żonę pochwycona na cudzolóstwie mąż może zabić natychmiast, nawet bez przeprowadzania postępowania sądowego. Zana natomiast, w przypadku cudzołóstwa męża, była bezradna, gdyż nie miała prawa nawet dotknąć go palcem. Stwierdzenie Katona dotyczy więc jedynie przy-

instituta ceriderunt,.. cum mulieres usque adeo vimo abstinerentur, ut matronam ob resignatos cellae vinariae loculos sui inedia necarint,...

${ }^{21}$ For. C. W. Westrup, dz. cyt., I, s. 201. który uważa, iż kobiety pijące wino mogły być nie tylko piętnowane przez cenzora, lecz także karane przez sędziego; W. Kunkel, dz. cyit., s. 236 sądzi, iz multa $w$ technicznym znaczeniu wslkazuje na karę pieniężną wymierzaną przez magistraturę, zaś zdaniem A. Söllnera, dz. cyt., s. 73 $i$ n. slowa mulctare uzywa Kato $w$ niatechinicznym znaczeniu, gdyz znaczenie techniczne przylgnęlo tylko do pojęcia multa; natomiast A. Watson, The Law of Persons in the Later Roman Republic, Oxford 1967 s. 69 i n. sugeruje, że w tym przypadku chodzi o ius retentionis przysługujące męzowi na posagu żony zarówno w przypadku picia wina jak i popelnienia adulterium.

22 Por. H. J. W olff, Das iudicium de moribus und sein Verhältnis zur actio rei uxoride, ZSS Rom. Abt. 54 (1934), który twwierdzi, że jest to mowa sadowa wygłoszona przez przeciwnika procesowego męża; natiomiast zdamiem W. Kunkla, dz. cyt., s. 234 uw. 26 jest to forma wypowiedzi typorwa dla konstrukcji języka lacińskiego, kiórej odpowiednikiem $w$ języku niemieckim jest bezosobowe man. 
padku zabójistwa żony-dokonanego inpune sine iudicio - złapanej in flagranti.

Przekaz Pliniusza wspomina także o bezkannym zabójstwie kobiety pijącej wino.

Plin. Nat. Hist. 14.89:

non licebat id (scil. vinum) feminis Romae bibere. invenimus inter exempla Egnati Maetenni uxorem, quod vinum bibisset e dolio, interfectam fusti a marito, eumque caedis a Romulio absolutum.

Historyk opowiadając anegdote o mężu, który swoją żonę złapaną na piciu wina $\mathrm{z}$ gąsiora zabil uderzając pałka, podaje, że Romulus uniewinnil go ${ }^{23}$. Wydaje się jednak, iz to rozstrzygnięcie, dotyczace jednostkowej sprawy, zostało rozciągnięte na wszystkie podobne wypadki, tworząc normę zgodnie $z$ którą, $w$ wypadku picia wina przez żonę mąż mógł ją zabić bezkarnie, podobnie jak w wypadku cudzołóstwa 24.

Zarówno picie wina jak i cudzołóstwo mogły być karane nie tylko 'w przypardku schwytania żony na gorącym uczynku.

Gell. 10.23.4:

Verba Marci Catonis adscripsi ex oratione quae inscribitur De Dote, in qua id quoque scriptum est, in adulterio uxores deprehensas ius fuisse maritis necare: "Vir", inquit, „cum divortium fecit, mulieri iudex pro censore est, imperium quod videtur habet, si quid perverse taetreque factum est a muliere, multitatur; si vinum bibit, si cum alieno viro probri quid fecit, condemnatur."

Przytaczając słowa Katona Gellius podnosi dwie kwestie 25: prawo męża do zabicia żony złapanej ina cudzołóstwie, oraz możność ukarania żony przez dokonanie $z$ nią rozwodu i związane $z$ tym skutki. Uwzględniając, iż Kato (Gell. 10.23.3) picie wina kobiet trakstuje na równi z cudzołóstwem, można przyjąć, że i w tym przypadku przewiduje on jednakową karę za oba przestępstwa. Hipoteza ta opiera się na rozróżnieniu multitare i condem-

23 Por. też Val. Max. 6.3.9: Egnati autem Metenni longe minore de causa, qui uxorem, quod vinum bibisset, fusti percussam interemit, idque factum non accusatore tantum, sed etiam repreherisore caruit, uno quoque existimante optimo illam exemplo violatae solbrietati poenas perpendisse. Serv. Ad Verg. A.en. 1.737: apud maiores nostros feminae non utebantur vino, nisi sacrorum causa certis diebus. Denique femina, quae sub Romulo vinum bibit, occissa est a marito, Metennius absiolutus, id enim nomen maritio. Tent. Apol. 6.29: ...cum midieres usque adeo vino abstinerentur, ut ... sub Romulo vero quae vinum adtigerat, inpune a Metennio marito trucidata sit.

24 P.or. A. Sölln er, dz. cyt., s. 75.

${ }^{25}$ Tekst cyt. na podstawie J. C. Rolfe, The Attic Nights of Aulus Gellius, London 1948, lecz ze zmienioną interpunkicją. 
nare 26 oraz przyjęciu następującej konstrukcji wypowiedzi Katona: ... si quid perverse taetreque factum est a muliere, multitatur; si vinum bibit, si cum alieno viro probri quid fecit, condemnatur 27. Za konstrukcją tą opowiada się też Söllner 28, podnosząc iz opis stanu iaktycznego $w$ zdaniu warunkowym (si... factum est; si... bibit; si... fecit) jest $w$ stylu starych ustaw (si in ius vocat), jak równiez to, iz $w$ dużej części tesiktów klasycznych opis taki występuje $\mathrm{w}$ zdaniu podrzędnie złożonym. Uznaje on również konstrukcję alternatywną multatur, si vinum bibit; si cum alieno viro probri quid fecit, condemnatur w stylu Katona za ekscentryczny chiasmus 29.

Jedinakże mowa Katona dotycząca jurysidykcji sądowej - ze względu na stylistyczną nieprecyzyjność - budzi dalsze kontrowersje ${ }^{30}$. Powodem tych kontrowersji jest składnia cytowanego zdania złożonego i ustalenie, które jego frazy są zdaniem glównym, a kitóre pobocznym; a zatem, które słowo stanowi podmiot zdania glównego. Noailles 31, powołując sie na analogiczne przypadki w litenaturze rzymskiej, twierdzi, że słowo vir jest podmiotem zdania podrzędnego, a iudex podmiotem zdania głównego. Zatem Kato mówił o osobie sędziego, a nie o osobie męża-sędziego, który, w razie wytoczenia skargi cywilnej w związku. z rozwodem nakłada na żonę występną sankcję pieniężną proporcjonaliną do jej wykroczenia. Wykroczenia te były albo ciężkie, jak adulterium i picie wina, albo lżejsze, których nie wylicza. Postępowanie sądowe zdaniem Noailles'a toczy się nie w iudicium domesticum, lecz $\mathrm{w}$ iudicium de moribus 32. Natomiast Kunkel 33 uważa, iż vir przed zdaniem z cum jest podmiotem zdamia glów-

26 Por. W. Kunke1, dz. cyt., s. 235 i n. Odmienneg. zdania jest H. J. W olff, dz. cyt., s. 519 u'w. 4, który uważa iż są to słowa użyte zamiennie.

27 Por. C. W. Westrup, dz. cyt., I, s. 201 uw. 1; P. Noailles, dz. cyt., s. 26 uw. 1; W. Kunkel, dz. cyt., s. 234; A. Söllner, dz. cyt., s. 71 .

28 Par. A. Söllnelr, dz. cyt., s. 71 i n. uw. 3.

29 Por. J. C. Rolfe, dz. cyt., ad h.1.; E. Volterra, dz. cyt., s. 115; D. Kienast, Cato der Zensor, seine Persönlichkeit und seine Zeit ${ }^{2}$, Darmstadt 1979 , s .166 .

\$0 Por. E. Volterra, dz. cyit., s. 115 uw. 119 kitóry poraje prizykłady różnych komentarzy tego fragmentu z rozmaitymi próbami jego rekonstrukcji.

31 Pcr. P. Noailles, dz. cyt., s. 26 ww. 1. Por. też. A. Sölliner, dz. cyt., s. 72 uw. 6.

32 Por. A. Noailles, dz. cyt.,s. 26 i n. Na temat iudicium de moribus por. Kl ingmülle r, RE IX, Stuttgart 1916, s.v. Iudicium de moribus, szp. 1083 i n.; H. J. Wolff, dz. cyt., s. 315 i n.; E. Volterra, NNDI IX, Torino 1965, s.v. Iudicium de moribus, s. 344 i n.; $\mathrm{Na}$ temat stosunku iudicium de moribus do actio rei uxoriae por. A. Söllner, dz. cyt., s. 80 i n. 
nego, którego dopełnieniem jest iudex pro censore est. Vir jest pordmiotem także następnego zdania (vir) imperium quod videtur habet. Mąz zatem w przypadku złego prowadzenia się żony (propter mores) wzorując się na cenzorskim sądzie abyczajowymª (vî̀... iudex pro censore esi) przy zwrocie posagu po rozwiazanic malżeństwa korzysta $z$ ius retentionis ${ }^{35}$. Wladza męża nad żoną jest upodobniona do wladzy magistratury nad obywatelami. Przysluguje więc męzowi tzw. (quod videtur) imperium nad żona przy liejszych wykroczeniach (si quid perverse taetreque factum est a muliere) czyli prawo karcenia (Multierungsrecht), natomiast przy przestępstwach takich jak picie wina czy cudzolóstwo jurysdykcja sadowa ${ }^{36}$. Rozróżnionie multitari i condemnari pozwala KunkJowi przyjąc, że tak jak arbitralna władza magistratury wobec obywatela była ograniczona do lzejszych przestępstw, tak analogicznie przyskugujące męzowi prawo karcenia zony ograniczone bylo do lżejszych wykroczeń. Ukkaranie zaś cięzkich przestępstw tak obywatela jak $i$ zony następowało $w$ drodze wyroku. Wyrok na żonę wydawano jednak w ramach iudicium domestiıum ${ }^{37}$.

Skladnia gramatycana przytoczonej przez Gelliusa mowy Katona (Gell. 10.23.4) nie pozwala stwierdzić, czy sędzią był sędzia prywatny, czy też sędzią byl mąż 38 . Z jednej strony jest bezsporne, iz mąz ma prawo zalbicia żony w wypadku zlapania jej na cudzołóstwie (Gell. 10.23.5). Prawo to potwierdza także Dionysios (Dion. 2.25.6). Mąż może również bezkarnie zabić żonę złapaną na piciu wina (Plin. Nat. Hist. 19.89; Val. Max. 6.3.9). Zabranie wluczy do piwnic $z$ winem czy picie wina może pociagać za soba takie kare wymierzana, zdaniem Dionysiosa (Dion. 2.25.6) i $\mathrm{Fa}$ biusa Pictora cytowanego przez Pliniusza (Plin. Nat. Hist. 14.89), w ramach iudicium domesticum. Z drugiej strony Gellius (Gell. 10.23.1) podaje, iż czlonkowie rodziny kontrolowali czy kobiety pily wino. Na podstawie tej wypowiedzi można równiez wnioskować, że były one karane przez swych krewnych. Ponadto z dalszej wypowiedzi Katona wynilka, iz kobiety mogły być karane

${ }^{33}$ Por. W. K unke1, dz. cyt., s. 234 uw. 28.

${ }^{24}$ Por. E. Pólay, dz. cyt., s. 314 , który twierdzi, że w tym fragmencie jest mowa o jurysdykcji publicznej przysługującej mężowi.

${ }_{35}$ Por. W. Kunke1, dz. cyt., s. 234 i n. Por. też. A. Watson, dz. cyt., s. 69 i $\mathrm{n}$.

${ }_{36}$ Por. W. K. unkel, dz. cyt., s. 235 i n. M. K a s er, $R P R^{2}$, I, s. 57 uw. 5, twiendzi, iz słowo imperium wystepuje zamiast potestas czy manus.

37 Por. W. Kunkel, dz. cyt., s. 336 i n.

s Por. A. Sollner, dz. cyt., s. 72. Wediug H. J. Woliffa, dz. cyt., s. 319 i n. showo iudex w Gell. 10.23.3. jest uzyte na oznaczinie sedziego, natomiast w Gell. 10.23.4 - męża. Natomiast Kl ing mülle r, dz. cyt., szp. 1083, uważa, iż mąz występuje jako iudex domesticus. Por. teź E. Pól ay, dz. cyt., s. 314 i n. 
także przez sędziego. Kato nie podaje, czy w tym wypadku sędzią był mąz, lecz mówi ogólnie iudex. Nasuwa to przypuszczenie, iż obok męża uprawniona do karania kobiet była także inna osoba. A zatem mąz nie jest sędzią, o którym mówi Kato. $\mathrm{Z}$ tego można wysnuć wniosek, że w wypowiedzi Katona nie chodziło o wymiar kary $w$ ramach ogólnych uprawnień męża do karcenia żony, czy nawet w ramach iudicium domesticum, gdyż używając slowa quoque Kato stwiendza nie tylko, ze taki wymiar kary mógł mieć miejsce, lecz także, że obok niego istnial wymiar kary dokonywany przez sędziego. Sędzia ten, być może w ramach iudicium de moribus, ustalal czy zaistnialy przesłanki rozwodowe i jak cięzkie było wykroczenie kobiety oraz wymierzał odpowiednia kare. Wedlug omawianej mowy Katona o posagu (Gell. 10.23.4), kobieta była zasądzana (condemnoíur) $z$ powodu cudzolóstwa i picia wina; przy innych wylkroczeniach byla karana (multitatur). Oznacza to, być może, że w pierwszym z przytoczonych przypadków, które później zostały uznane za mores graviores, kobieta tracila cały swój posag, a mozie nawet była skazywana na karę śmienci (Dion. 2.25.6; Plin. Nat. Hist. 14.89), podczas gdy w przypadku lżejszych wykroozeń - mores leviores - musiała mężowi pozostawić część posagu ${ }^{39}$. Ocena mores kobiety nalezała więc do sędziego i dlatego wydaje się zrozumiałe, że jeśli mąż dokonywal rozwodu $i \mathrm{w}$ wyniku tego rozpatrywano sprawe o zwrot posagu, sędzia wystepowal w roli cenzora 40 .

Plutarch wskazuje także, że obowiązek wydania żonie części posagu pochodri z czasów Romulusa.

Plutarchus, Romulus 22 = Leges regiae, Romulus 9 (FIRA I, 8): ... si vero aliter (scil. non propter veneficium circa prolem, vel subiectionem clavium, vel adulterium commissum) quis a se dimitteret uxorem, bonorum eius partem uxoris fieri, partem Cereri sacram esse iussit (scil. Romulus); ...

Wedkug cytowanej już poprzednio ustawy przypisywanej Romulusowi, kobieta nie mogła odejść od męża, natomiast mąż mógł porzucić żonę, gdy poipelniła ona ciężkie przestępstwo. Gdyby zaś oddalił żonę $z$ innych powodów, winien jej oddać część posagu, a część przekazać na rzecz bogini Ceres ${ }^{41}$.

Wydaje się, iż sprawy dotyczące zwrotu posagu, przynajmniej już na początku II wieku p.n.e., rozpatrywał sędzia, a nie mąż. Za taką hipotezą przemawia również przekaz Pliniusza.

Plin. Nat. Hist. 14.90:

... Cn. Domitius iudex pronuntiavit mulierem videri plus vini

39 Por. A. Söllner, dz. cyt., s. 73 i n.; A. Watson, dz. cyt., s. 69.

40 Inaczej E. Pól a y, dz. cyt., s. 315 i n., twierdząc, iż to mąz w stosunku do żony pelni rolę cenzora.

41 Por. P. Noailles, dz. cyt., s. 2. i n. 
bibisse quam valitudinis causa, viro insciente, et dote multavit. diuque eius rei magna parsimonia fuit.

Pliniusz, który czerpie wiadomości prawdopodobnie $\mathrm{z}$ tego samego źródla co Gellius, podaje rozstrzygnięcie sędziego Domitiusa 42 wydane przy okazji rozpatrywania sprawy o picie wina przez kobietę. Kobxieta ta pila wino bez wiedzy męża - i to nie w celach leczniczych - za co została ukarana utrata posagu.

Jak z powyższych rozważań wynika, za picie wina kobieta była karana, bądź przez swego męża, który mial prawo zabicia żony złapanej na gorącym uczynku, bądź przez swych krewnych, prawdopodobnie $w$ ramach iudicium domesticum, bądź wreszcie przez sędziego, może w ramach iudicium de moribus, na utratę posagu.

\section{Si mulier vinum bibit condemnatur}

Gelljus (Gell. 10.23.1-2), reffering to the victus and mores of the early Romain women, tells us that the durinking of wine (temetum) was forbididen to women. They were only allowed to dinink the lorea, passum, murrina, and other sweet-tasting drinks of that kind. If women drank whine ciould be punished with the same severity as dultery (Diion. 2.25.6; Gell. 10.23.3). Catto, cited by Gellius (Gell. 10.23.5), has stated that the hasband has right to kill his wife taken in adultery. As regards repudation, says he, in the oration entitled On the Dowry (Gell. 10.23.4), that iudex has the function of censor. If woman has been guility of any wrong or shameful act, she is punished (multitatur), lif she has drunk wine or if she has done wrong with another man, she is candemned (condemnatur).

42 Por. P. Noailies, dz. cyt., s. 8 is n. 